\title{
Reports of new wing color polymorphism and taxonomic information to cercopids (Auchenorrhyncha: Cercopidae) from upland rice crop, Pará State, Brazil
}

\author{
A. Paladini ${ }^{a *}$, A. C. Domahovski ${ }^{b}$ D. Krinskic and L. A. Foerster ${ }^{\text {d }}$ \\ ${ }^{a}$ Departamento de Ecologia e Evolução, Universidade Federal de Santa Maria - UFSM, \\ Avenida Roraima, $n^{\circ}$ 1000, Camobi, CEP 97105-900, Santa Maria, RS, Brazil \\ ${ }^{b}$ Departamento de Zoologia, Universidade Federal do Paraná - UFPR, Avenida Coronel Francisco H. dos Santos, \\ $\mathrm{n}^{\circ}$ 100, Centro Politécnico, Jardim das Américas, CP 19020, CEP 81531-980, Curitiba, PR, Brazil \\ 'Departamento de Ciências Biológicas, Universidade do Estado de Mato Grosso - UNEMAT, \\ Rodovia MT 358, Km 7, Jardim Aeroporto, CP 287, CEP 78300-000, Tangará da Serra, MT, Brazil \\ dDepartamento de Zoologia, Universidade Federal do Paraná - UFPR, Avenida Coronel Francisco H. dos Santos, \\ $n^{\circ}$ 100, Centro Politécnico, Jardim das Américas, CP 19031, CEP 81531-980, Curitiba, PR, Brazil \\ *e-mail: andri.paladini@gmail.com
}

Received: February 7, 2017 - Accepted: May 10, 2017 - Distributed: November 30, 2018

(with 36 figures)

\begin{abstract}
Cercopidae is one of the largest families of the spittlebug superfamily Cercopoidea. Most spittlebugs species are characterized by bright color patterns. Thus, this study evaluated for the first time the Cercopidae species collected in rice crops, Novo Progresso, Pará state, Brazil. Insects were collected weekly between November/2010 and March/2011 from areas without (WA) and with agrochemical applications (AA). Four species were recorded: Deois incompleta (Walker, 1851) (71 specimens in WA area and 50 in AA area); Mahanarva spectabilis (Distant, 1909) (39 specimens in WA area and 39 in AA area); Mahanarava tristis (Fabricius, 1803) (26 specimens in WA area and 20 in AA area); Zulia pubescens (Fabricius, 1803) (11 specimens in WA area and four in AA area). The species collected displayed pronounced color polymorphism when compared with the color patterns of the same species from other regions. This makes correct identification more difficult for these species. Therefore, taxonomic and diagnostic informations provided in this study will help in the correct identification, control and monitoring of these insects in future studies. Besides that, we recommend monitoring in rice fields and further study of the biology and ecology of cercopids in Brazil to assess the potential of these species as rice pests.
\end{abstract}

Keywords: Cercopoidea, Deois incompleta, Mahanarva spectabilis, Mahanarva tristis, Zulia pubescens.

\section{Registro de novos polimorfismos de cores de asas e informações taxonômicas para cercopídeos (Auchenorrhyncha: Cercopidae) com potencial importância econômica na cultura de arroz de terras altas, Estado do Pará, Brasil}

\begin{abstract}
Resumo
Cercopidae é uma das maiores famílias de cigarrinhas dentro da superfamília Cercopoidea. A maioria das espécies de cigarrinhas é caracterizada pelos padrões de cores brilhantes. Deste modo, este estudo avaliou pela primeira vez, as espécies de Cercopidae coletados em cultura de arroz, Novo Progresso, Pará, Brasil. Os insetos foram coletados semanalmente entre novembro/2010 e março/2011 em áreas de arroz de terras altas sem (SA) e com aplicações de agroquímicos (CA). Quatro espécies foram registradas: Deois incompleta (Walker, 1851) (71 espécimes na área SA e 50 na área CA); Mahanarva spectabilis (Distant, 1909) (39 exemplares na área SA e 39 na área CA); Mahanarava tristis (Fabricius, 1803) (26 espécimes na área SA e 20 na área CA); Zulia pubescens (Fabricius, 1803) (11 espécimes na área SA e quatro na área CA). As espécies coletadas exibiram um polimorfismo de cor pronunciado quando comparadas com os padrões de cores das mesmas espécies de outras regiões. Isso torna mais difícil a identificação correta dessas espécies. Portanto, as informações taxonômicas e de diagnóstico fornecidas neste estudo ajudarão na identificação, controle e monitoramento desses insetos em estudos futuros. Além disso, recomendamos o monitoramento em campos de arroz e estudos posteriores de biologia e ecologia de cercopídeos no Brasil para avaliar o potencial dessas espécies como pragas de arroz.
\end{abstract}

Palavras-chave: Cercopoidea, Deois incompleta, Mahanarva spectabilis, Mahanarva tristis, Zulia pubescens. 


\section{Introdution}

The rice crop (Oryza sativa L.) (Poales: Poaceae) occupies approximately $10 \%$ of the world arable land. Rice cultivation began in South Asia and at present rice is grown in more than 110 countries (Heinrichs, 1994;IRRI, 2006). Brazil is the largest producer of rice outside Asia, even with its recent cultivation compared to the Asian continent (Azambuja et al., 2004, FAO, 2003). According to the Brazilian Harvest Monitoring 2012/2013 report of the Companhia Nacional de Abastecimento/National Supply Company (Conab, National Company of Food Supply), the Brazilian states with the highest production (Rio Grande do Sul, Santa Catarina, Mato Grosso, Maranhão, Tocantins and Pará) account for approximately $80 \%$ of the national rice production (Ferreira and Villar, 2004; IRGA, 2009). Some environmental factors interfere negatively on crop production; among these, insects are responsible for much of the losses from germination to harvest, mainly due to mechanical damage and the transmission of plant pathogens (Ferreira et al., 2001; SOSBAI, 2005; Martins et al., 2009).

Insects in the hemipteran suborder Auchenorrhyncha commonly occur in rice crops. Twenty-two planthopper species in the family Delphacidae and 34 leafhopper species in the family Cicadellidae occur in rice in South and South-East Asia (Wilson and Claridge, 1991). Several spittlebug species (family Cercopidae) are also known to damage rice crops. Some planthoppers can damage rice plants by direct feeding, which causes a symptom known as 'hopperburn'. These insects have been major threats to rice cultivation since the 1960s and 1970s and can be considered devastating pests. Both planthoppers and spittlebugs are vectors of a variety of rice diseases (Heong et al., 1992). However, little is known about the cercopid species considered pests in South America and their effects on this crop.

Cercopidae is one of the largest families of the spittlebug superfamily Cercopoidea, which are xylem-sap sucking insects. Most species are characterized by bright color patterns and are commonly referred as spittlebugs due to the production of protective froth excreta by the nymphs. Neotropical spittlebugs are classified in the subfamily Ischnorhininae, and are of concern to agriculture in Brazil because of their potential to cause significant damage to economically important plants. Cercopids feed on a variety of plants: several species in the genera Aeneolamia Fennah, Deois Fennah, Isozulia Fennah, Notozulia Fennah, Prosapia Fennah and Zulia Fennah are known to cause significant damage to forage grasses and sugarcane by direct feeding (Peck et al., 2001, Carvalho and Webb, 2005). Adult feeding can cause phytotoxemia and chlorosis. Severe outbreaks results on the yellowing of the entire aerial portion of the plant.

Thus, this study aimed to identify and characterize the main species of spittlebugs associated with upland rice crop in Novo Progresso, southwest region of Pará state (Brazil).

\section{Materials and Methods}

Insects were collected between Nov 2010 and Mar 2011 in two areas of upland rice cultivation: one with the application of agrochemicals (AA) $\left(7.122231^{\circ} \mathrm{S} 55.429211^{\circ} \mathrm{W} 222 \mathrm{~m}\right)$ and one without the application of agrochemicals (WA) (7.127903 $\left.{ }^{\circ} \mathrm{S} 55.430328^{\circ} \mathrm{W} 235 \mathrm{~m}\right)$. Samples were collected weekly, following a straight-line transect with a sweeping net, from planting season to harvest. The sampling effort was 16 sweeps in each area, four points of sweep (at each 25 meters) following a transect of 100 meters, covering approximately 400 meters in four transects of 100 meters, located at a distance of 25 meters from each other. A total of 250 cercopids were collected on the two areas.

Identifications were made with the aid of dichotomous keys, published species descriptions and comparison with photographs of type specimens. Genitalic structures were detached from the abdomen and boiled in $\mathrm{KOH}$ solution $10 \%$. The dissected parts were stored in micro vials with glycerin. Photographs were obtained with a Leica DFC-550 digital camera attached to the stereomicroscope (Leica MZ16) and captured and montaged with the software IM50 (Image Manager; Leica Microsystems Imaging Solutions Ltd, Cambridge, UK). Illustrations were drawn with the aid of a camera lucida and the final images made with Adobe Illustrator.

\section{Results}

Four species were recorded: Deois incompleta (Walker, 1851) (71 specimens in WA area and 50 in AA area); Mahanarva spectabilis (Distant, 1909) (39 specimens in WA area and 39 in AA area); Mahanarava tristis (Fabricius, 1803) (26 specimens in WA area and 20 in AA area); Zulia pubescens (Fabricius, 1803) (11 specimens in WA area and four in AA area). The study design did not allow for a statistical analysis of pesticide application affects, but a slightly higher abundance of cercopids was observed in areas without application of agrochemicals. In addition, it is important to note that most pest cercopids species exhibit color polymorphism, making the identification somewhat difficult, so taxonomic papers are extremely important because they help in the control and monitoring of these insects.

\subsection{Taxonomy of the species}

Deois incompleta (Walker, 1851) (Figures 1-9)

Habitus (Figures 1-2): Head light brown with suprantenal margin yellowish brown, compound eyes brown, rounded, arranged transversely; ocelli closer to each other than to compound eyes; tylus smooth and rectangular with a slightly marked median carina; vertex smooth, rectangular, with a median carina slightly marked; antennae brown, pedicel sparsely setose, basal body of flagellum globose, with one arista smaller than pedicel; postclypeus dark brown, inflated, rounded in profile, with a longitudinal carina strongly marked; lateral grooves strongly marked, rostrum reaching mesocoxae. Thorax brown; pronotum brown, hexagonal, with a median carina slightly marked; 
pronotum with anterior margin straight, lateral-anterior margins straight, lateral posterior margin slightly sinuous, posterior margin grooved; scutellum brownish with slight central concavity, tegmina brown with a longitudinal white band beginning on the basal portion extending until the claval apex, another white band on the costal margin and a white spot between the median and apical third; apical plexus of veins developed; hindwings hyaline with brown venation, vein $\mathrm{Cu} 1$ thickened at base; legs light brown with tarsi dark brown; metathoracic tibia with two lateral spines (basal spine equal in size to spines in apical crown; apical spine larger than spines in apical crown); apical crown of spines on tibia consisting of two rows; basitarsus with two rows of spines covered by long setae; subungueal process present and quadrangular. Abdomen brown.

Male genitalia: Pygofer with a rounded process between the anal tube and subgenital plates (Figure 5); subgenital plates long, dorsal margin forming a rounded elevation near the basal portion, apex bilobate (Figure 6); paramere slender with one apical, hook-like spine directed forward, dorsal margin slightly elevated (Figure 7); aedeagus slender, hammer-shaped, curved in lateral view; in dorsal view apex with two pairs of processes x-shaped, shaft with two rows of small spines located near the apex (Figures 8-9).

Remarks: This species exhibits color polymorphism (Figures 1-4). In some specimens the white longitudinal band located on the costal margin is less apparent and two vertical bands are present (Figures 3-4), the first located between the basal and median third and the second between the median and apical third.

Mahanarva spectabilis (Distant, 1909) (Figs. 10-18)

Habitus (Figures 10-11): Head reddish castaneous; compound eyes brown, rounded, arranged transversely; ocelli closer to each other than to compound eyes; tylus smooth and rectangular with a median carina a slightly marked; vertex smooth, rectangular with a median carina slightly marked; antennae castaneous, pedicel sparsely setose, basal body of flagellum subcylindrical, with one arista smaller than pedicel; postclypeus dark brown, inflated, angled in profile, with a longitudinal carina strongly marked; lateral grooves strongly marked, rostrum reaching mesocoxae. Thorax brownish red; pronotum brown, hexagonal, with a median carina strongly marked; pronotum with anterior margin straight, lateral-anterior margins straight, lateral posterior margin slightly sinuous, posterior margin grooved; scutellum brownish with slight central concavity, tegmina castaneous, apical plexus of veins developed; hindwings hyaline with brownish venation, vein $\mathrm{Cu} 1$ not thickened at base; legs brownish red; metathoracic tibia with two lateral spines (basal spine equal in size to spines in apical crown; apical spine larger than spines in apical crown); apical crown of spines on tibia consisting of two rows; basitarsus with three rows of spines covered by long setae; subungueal process present and triangular. Abdomen brown.

Male genitalia: Pygofer with a digit-like process between anal tube and subgenital plates (Figure 14); subgenital plates long with a slender apex, basal portion of dorsal margin rounded (Figure 15); parameres with one subapical spines, quadrangular and truncated, directed downward, dorsal margin rounded (Figure 16); aedeagus long as slender with a pair of flattened hook-like dorsal process inserted on the median portion of the shaft (Figures 17-18).

Remarks: This species exhibits color polymorphism, with both red (Figures 12-13) and black (Figures 10-11) specimens. However, the species is easily distinguished by paramere shape and by the quadrangular paramere spine.

Mahanarva tristis (Fabricius, 1803) (Figures 19-29)

Habitus (Figures 21-22): Head brownish red; compound eyes black, rounded, arranged transversally; vertex smooth, rectangular, with a prominent median carina; ocelli closer to each other than to compound eyes; tylus smooth and rectangular with a prominent median carina; antennae brownish red, pedicel sparsely setose, basal body of flagellum ovoid with one arista as long as pedicel; postclypeus brownish red, inflated, angulose in profile, with one longitudinal carina strongly marked and prominent, lateral grooves strongly marked; rostrum extending to mesocoxae. Thorax brownish; pronotum brownish red, hexagonal, curved, with a median carina slightly marked; pronotum with anterior margin straight, lateral-anterior margins straight, lateral posterior margin slightly sinuous, posterior margin grooved; scutellum brownish with slight central concavity, with horizontal grooves strongly marked; tegmina black with basal third yellowish orange and a yellowish orange stripe between the median third and the beginning of apical third, apical plexus of veins developed; hindwing hyaliane with brown venation, vein $\mathrm{Cu} 1$ not thickened at base; legs brownish red with meso and metathoracic femora black, metathoracic tibia with two lateral spines (basal spine equal in size to spines in apical crown; apical spine larger than spines in apical crown); apical crown of spines on tibia consisting of two rows; basitarsus with three rows of spines covered by long setae; subungueal process present and triangular. Abdomen black.

Male genitalia: Pygofer with a rounded process between anal tube and subgenital plates (Figure 25); subgenital plates long, basal portion of dorsal margin rounded (Figure 26); parameres with two subapical spines directed downward, dorsal margin rounded (Figure 27); aedeagus long and slender with a pair of flattened dorsal straight processes with slightly divergent apex, inserted on the median portion of the shaft (Figures 28-29).

Remarks: This species exhibits extensive color polymorphism. The color form described herein has never been documented before (Figures 21-22). The spots on the tegmina can be smaller, and the body coloration can be black (Figures. 19-20, 23-24).

Zulia pubescens (Fabricius, 1803) (Figures 30-36)

Habitus (Figures 30-31): Head black with a metallic shine, compound eyes black, rounded, arranged transversely; ocelli closer to each other than to compound eyes; tylus smooth and rectangular with a prominent median carina; vertex smooth, rectangular, with a prominent median carina; antennae black, pedicel sparsely setose, basal body of flagellum globose, inserted inside the pedicel, with one 
arista smaller than pedicel; postclypeus black, inflated, forming an acute angle in profile, with one longitudinal carina strongly marked and prominent, lateral grooves slightly marked, rostrum reaching mesocoxae. Thorax black; pronotum black, hexagonal, with a median carina strongly marked; pronotum with anterior margin straight, lateral-anterior margins straight, lateral posterior margin slightly sinuous, posterior margin grooved; scutellum
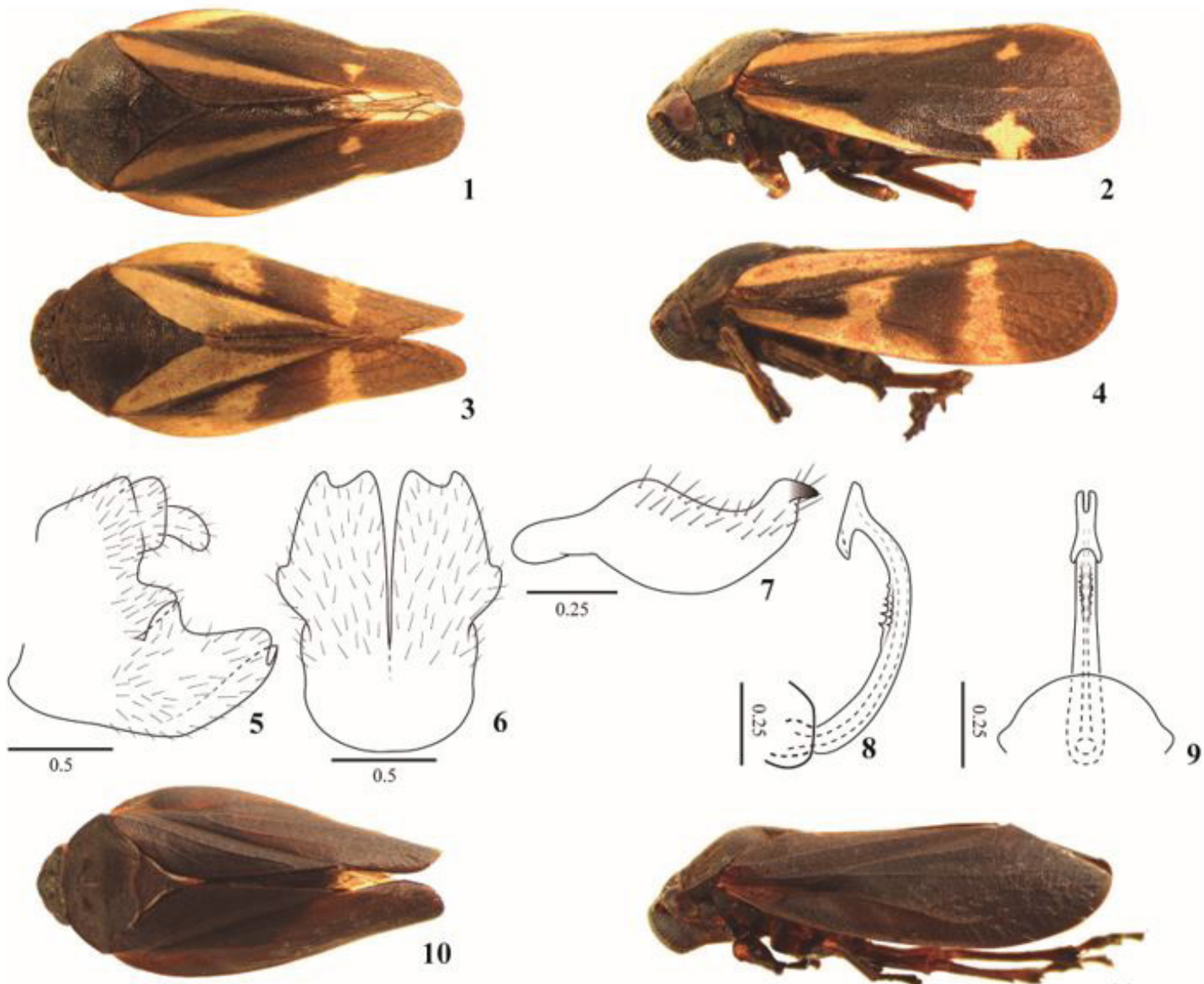

10
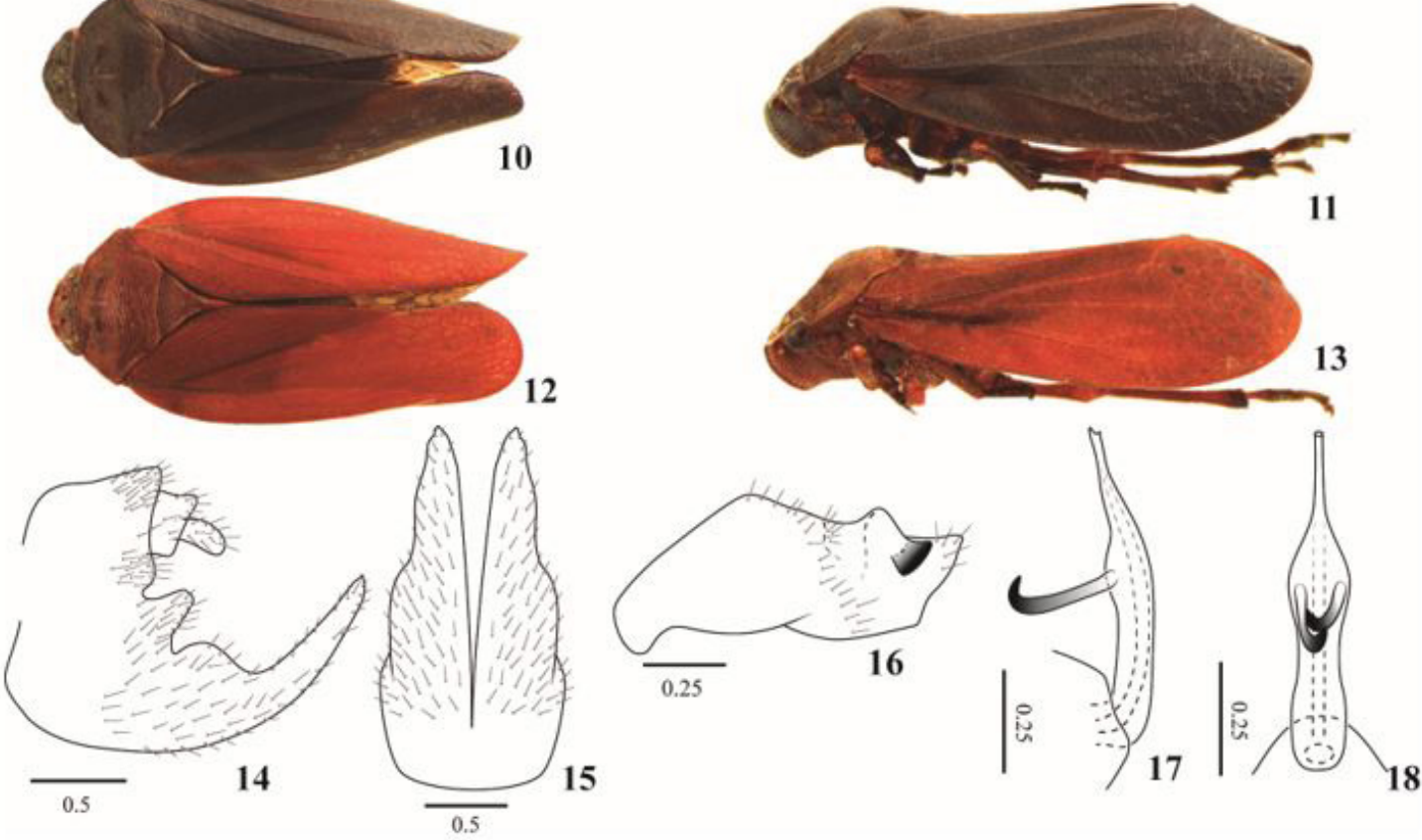

Figures 1-18. Deois incompleta - Dorsal and lateral habitus: 1-4; Male genitalia: 5. Pygofer, lateral view; 6. Subgenital plates, ventral view; 7. Paramere, lateral view; 8. Aedeagus, lateral view; 9. Aedeagus, ventral view. Mahanarva spectabilis Dorsal and lateral habitus: 10-13; Male genitalia: 14. Pygofer, lateral view; 15. Subgenital plates, ventral view; 16. Paramere, lateral view; 17. Aedeagus, lateral view; 18. Aedeagus, ventral view. Scale bars in mm. 
brownish with slight central concavity, with horizontal grooves strongly marked; tegmina black, apical plexus of veins developed; hindwings hyaline with dark brown venation, vein $\mathrm{Cu} 1$ not thickened at base; legs black; metathoracic tibia with two lateral spines (basal spine equal in size to spines in apical crown; apical spine larger than spines in apical crown); apical crown of spines on tibia consisting of two rows; basitarsus with two rows of
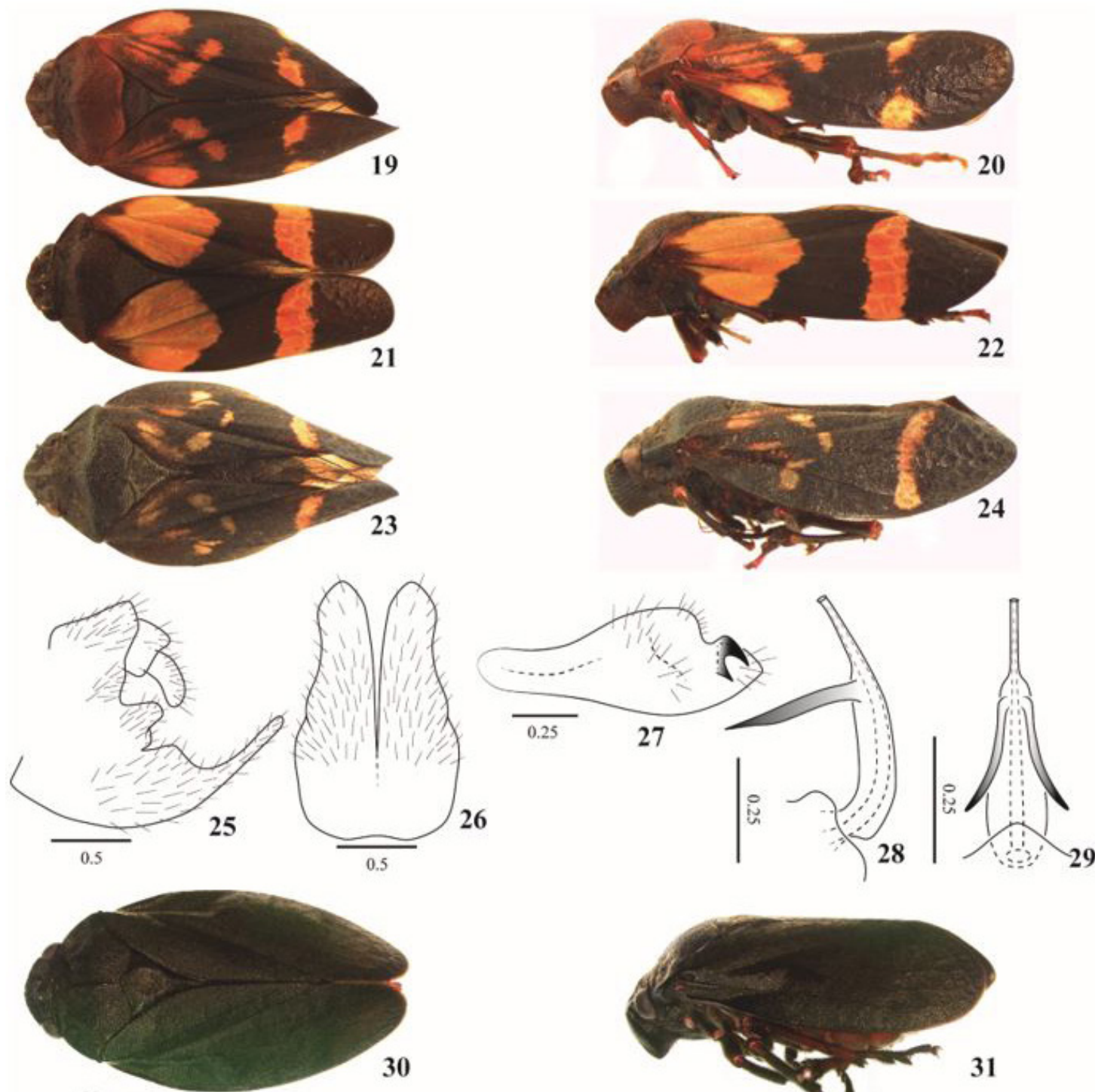

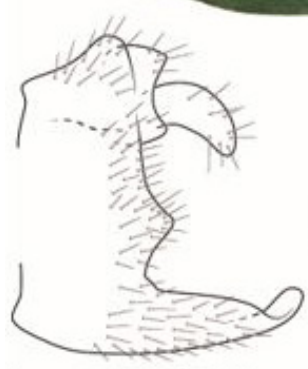

0.5
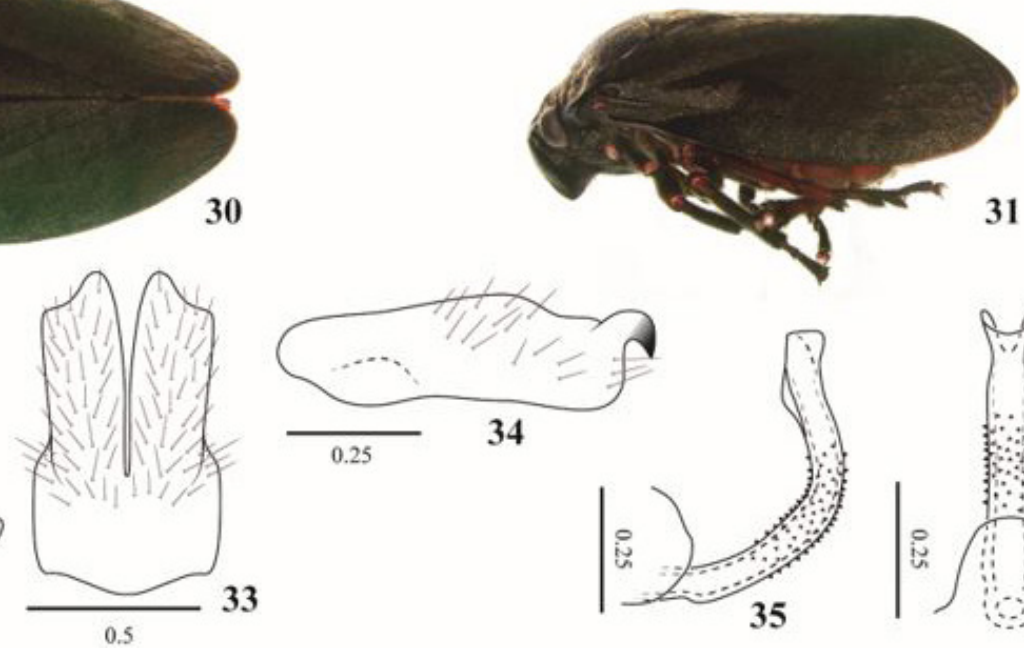

31

34

0.25
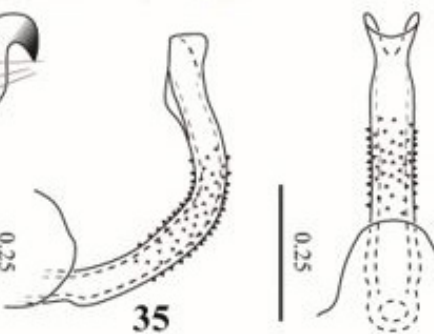

36

Figures 19-36. Mahanarva tristis - Dorsal and lateral habitus: 19-24; Male genitalia: 25. Pygofer, lateral view; 26. Subgenital plates, ventral view; 27. Paramere, lateral view; 28. Aedeagus, lateral view; 29. Aedeagus, ventral view. Zulia pubescens Dorsal and lateral habitus: 30-31; Male genitalia: 32. Pygofer, lateral view; 33. Subgenital plates, ventral view; 34. Paramere, lateral view; 35. Aedeagus, lateral view; 36. Aedeagus, ventral view. Scale bars in $\mathrm{mm}$. 
spines covered by long setae; subungueal process present and quadrangular. Abdomen black.

Male genitalia: Pygofer with an inconspicuous rounded process between the anal tube and subgenital plates (Figure 32); subgenital plates long, dorsal margin straight, apex twisted (Figure 33); parameres with an apical hook-like spine directed downward, dorsal margin straight (Figure 34); aedeagus slender, shaft without processes, basal and median portion covered with small teeth, apex cup-like (Figures 35-36).

Remarks: This species does not exhibit color polymorphism and is easily distinguished by the angular shape (forming an acute angle) of the postclypeus.

\section{Discussion}

The economic importance of cercopids results from the fact that these insects debilitate the host plants due to continuous sucking sap and injection of toxins, resulting in leaf chlorosis (Nilakhe et al., 1984). Several cercopids species are found on upland rice worldwide: Deois schach (Fabricius), Denoplux nigropunctata (Stål), Deois flexuosa (Walker), Deois flavopicta (Stål), Deois incompleta (Walker), Zulia entreriana (Berg), Mahanarva fimbriolata (Stål), Aeneolamia spectabilis (Distant,), Aeneolamia varia (Fabricius), Aeneolamia postica (Walker), Abidama producta (Walker), Locris maculata (Fabricius) and Locris rubra (Fabricius) (Dean, 1978; Rossetto et al., 1978; Ferreira and Martins, 1984; Nilakhe, 1985; Ferreira, 2006; Sere et al., 2008; Nwilene et al., 2009; Onasanya et al., 2012; Koudamiloro et al., 2015).

The practice of planting monoculture pastures in the North and Central regions of Brazil, an increasing trend in recent years, has resulted in population increases in auchenorrhynchous insects in general, leading in turn to increased economic damage to the cultivated crops. These losses are documented in pasture grasses and other important crops such as rice, sugarcane and maize (Nilakhe, 1985; Hewitt, 1988; Cosenza et al., 1989; Cruz et al., 2010). In several regions of Brazil where upland rice fields are surrounded by pastures, severe damage occurs from migrating adults when the grasses become unfavorable hosts. Significant areas occupied by rice and corn, especially in the states of Mato Grosso do Sul, Goiás, Minas Gerais and more recently, Mato Grosso have been infested by these insects (Bernardo et al., 2003).

The presence of these insects in different crops, even in small numbers as observed in our work, is an indication that they may become potential pests for upland rice cultivated in Pará state. According to Ferreira et al. (2003), Auchenorrhyncha are found in all regions of the world where rice is grown and in some regions have caused severe damage to rice fields because of its feeding activity and spread of diseases and viruses, such as countries in Asia and Central and South America (Rossetto et al., 1972; Wilson and Claridge, 1991).

These data are worrisome, especially since there are previous reports of the damage already caused by spittlebugs in other rice producing regions of Brazil. The first record of damage caused by Cercopidae in rice occurred in an irrigated crop in Rio Grande do Sul state, where D. flexuosa caused an estimated at 5\% loss (Pugliese and Terra, 1957). Subsequently, Rossetto et al. (1978) observed D. flavopicta and D. schach causing damage to upland rice in São Paulo state. However, the greatest damage was caused by D. flavopicta and Notozulia entreriana (Berg) in upland rice in the Central region of Brazil, where the area lost due to the attack of these insects was estimated at 52,000 ha in 1981/82 in Goiás state and 23,000 ha in 1983/84 in Mato Grosso do Sul state (Barbosa et al., 1983; Souza and Nilakhe, 1985).

Many species of spittlebugs commonly found in pastures have been observed attacking rice crops; for example, D. flavopicta occurs frequently and in large populations in the regions of highest concentration of upland rice and has been most damaging to the culture (Ferreira et al., 2003). Considering the information above, this group of insects deserves attention and should be monitored, especially in new agricultural frontiers, as in our study area, where many species of insects have been reported for the first time in several economically important crops (Krinski et al., 2012; Krinski and Pelissari, 2012; Krinski, 2013a, b,2015; Krinski and Godoy, 2015; Martins and Krinski, 2016; Krinski and Foerster, 2017).

In addition, taxonomic studies with Cercopidae occurring in different crops should be performed in these regions which are still poorly investigated, especially when considering the number of new species of spittlebugs that have been discovered in Brazil and in all Neotropical Region (Costa and Sakakibara, 2002; Paladini and Carvalho, 2007, 2013; Paladini, 2011; Paladini and Cryan, 2012; Paladini and Cavichioli, 2013,2014; 2015; Paladini et al., 2015). Therefore, documenting taxonomic information such as color polymorphism is important since the conspicuous color pattern of these insects may be related to factors such as camouflage coloration (Hamilton, 1982) and also escape warning coloration (Thompson, 1973). Peck (2000) considered that the colors displayed by Cercopidae is an important evolutionary characteristic of defense within the superfamily Cercopoidea.

Given the economic importance of rice crop in Brazil, we recommend careful monitoring in rice fields and studies of control, biology, morphology, ecology and taxonomy of Cercopidae in different rice varieties, mainly to verify if some species can become a potential pest for rice cultivation in the future, as already observed for others pest for upland rice crops in this region (Krinski and Foerster, 2016; 2017; Martins and Krinski, 2016).

\section{Acknowledgements}

Authors acknowledge the anonymous reviewers for providing comments and corrections on a draft of this paper, the farmers of the Dona Nena farm: Marlete Florentino, Eurides Florentino (in memorian) and Nadir de Lima Florentino (in memoriam) for allowing this research 
on their property. And thank also the Coordenação de Aperfeiçoamento de Pessoal de Nível Superior (CAPES) and the Conselho Nacional de Desenvolvimento Científico e Tecnológico (CNPq), for providing scholarships (ACD: process 130388/2015-7; DK: process 141243/2012-0).

\section{References}

AZAMBUJA, I.H.V., VERNETTI-JUNIOR, F.J. and MAGALHÃESJUNIOR, A.M., 2004. Aspectos socioeconômicos da produção de arroz. In: GOMES, A.S. and MAGALHÃES-JÚNIOR, A.M., eds. Arroz irrigado no sul do Brasil. Brasília: Embrapa, pp. 23-44.

BARBOSA, F.R., OLIVEIRA, Z.J. and MOREIRA, W.A., 1983. Danos causados em arroz pela cigarrinha-das-pastagens (Deois flavopicta (Stål, 1854). Goiânia: EMGOPA, 5 p. PesquisaemAndamento, no. 1.

BERNARDO, E.R.A., ROCHA, V.F., PUGA, O. and SILVA, R.A., 2003. Espécies de cigarrinhas-das-pastagens (Hemiptera: Cercopidae) no meio-norte do Mato Grosso. Ciência Rural, vol. 33, no. 2, pp. 369-371. http://dx.doi.org/10.1590/S010384782003000200030

CARVALHO, G.S. and WEBB, M.D., 2005. Cercopid spittlebugs of the New World (Hemiptera, Auchenorrhyncha, Cercopidae). Sofia: Pensoft, $280 \mathrm{p}$.

COSENZA, G.W., ANDRADE, R.P., GOMES, D.T. and ROCHA, C.M.C., 1989. Weed competition in maize-bean intercropping system. Pesquisa Agropecuária Brasileira, vol. 24, no. 8, pp. 961-968.

COSTA, A.C.F. and SAKAKIBARA, A.M., 2002. Reestruturação do gênero Deois Fennah; descrição de um novo gênero e de novas espécies (Homoptera, Cercopidae, Tomaspidinae). Revista Brasileira de Entomologia, vol. 46, no. 2, pp. 195-207. http:// dx.doi.org/10.1590/S0085-56262002000200012.

CRUZ, I., CORRÊA, M.L., GONTIJO-NETO, M.M. and SILVA, R.B., 2010. Danos da cigarrinha-das-pastagens, Deois flavopicta Stål (Homoptera: Cercopidae) em milho consorciado com braquiárias. Sete Lagoas: Embrapa Milho e Sorgo, 10 p. Circular Técnica, no. 144.

DEAN, G.J., 1978. Insects found on economic plants other than rice in Laos. Pest Articles \& News Summaries, vol. 24, no. 2, pp. 129-142. Currently International Journal of Pest Management.

FERREIRA, C.M. and VILLAR, P.M., 2004. Aspectos da produção e do mercado de arroz. Informe Agropecuário, vol. 25 , no. 222 , pp. 11-18.

FERREIRA, E. and MARTINS, J.F.S., 1984. Insetos prejudiciais ao arroz no Brasil e seu controle. Goiânia: Embrapa Arroz e Feijão, 67 p. Documentos, no. 11.

FERREIRA, E., 2006. Fauna prejudicial. In: A.B.SANTOS, L.F.STONE and N.R.A.VIEIRA, eds. A cultura do arroz no Brasil. 2. ed. Santo Antônio de Goiás: Embrapa Arroz e Feijão, pp. $485-560$

FERREIRA, E., BARRIGOSSI, J.A.F. and CASTRO, E.M., 2003. Homópteros associados ao arroz. Embrapa Arroz e Feijão, 44 p. Documentos, no. 152.

FERREIRA, E., BARRIGOSSI, J.A.F. and VIEIRA, N.R.A., 2001. Percevejo das panículas do arroz: fauna Heteroptera associada ao arroz. Santo Antônio de Goiás: Embrapa Arroz e Feijão, 27 p. Circular técnica, no. 43.
FOOD AND AGRICULTURE ORGANIZATION - FAO, 2003 [viewed 23 January 2017]. Agricultural production, primary crops [online]. Available from: http://www.fao.org

HAMILTON, K.G.A., 1982. The insects and arachnids of Canada - part 10: the spittlebugs of Canada (Homoptera: Cercopidae). Ottawa: Agriculture Canada publication 1740, $102 \mathrm{p}$.

HEINRICHS, E.A., 1994. Host plant resistance. In: HEINRICHS, E.A., ed. Biology and management of rice insects. New Delhi: IRRI, pp. 517-548.

HEONG, K.L., AQUINO, G.B. and BARRION, A.T., 1992. Population dynamics of plant- and leafhoppers and their natural enemies in rice ecosystems in the Philippine. Crop Protection (Guildford, Surrey), vol. 11, no. 4, pp. 371-379. http://dx.doi. org/10.1016/0261-2194(92)90066-E.

HEWITT, G.B., 1988. Grazing management as a means of regulating spittlebug (Homoptera: Cercopidae) numbers in Central Brazil. Pesquisa Agropecuária Brasileira, vol. 23, no. 7, pp. 697-707.

INSTITUTO RIO GRANDENSE DO ARROZ - IRGA, 2009 [viewed 23 January 2017]. Available from: http://www.irga.rs.gov.br INTERNATIONAL RICE RESEARCH INSTITUTE - IRRI, 2006. Rice today. Philippines: Metro Manilla, 30 p.

KOUDAMILORO, A., NWILENE, F.E., TOGOLA, A. and AKOGBETO, M., 2015. Insect vectors of rice yellow mottle virus. Journal of Insects, vol. 2015, pp. 1-12.

KRINSKI, D. and FOERSTER, L.A., 2016. Toxicity of essential oils from leaves of Piperaceae species in rice stalk stink bug eggs, Tibraca limbativentris (Hemiptera: Pentatomidae). Ciência e Agrotecnologia, vol. 40, no. 6, pp. 676-687. http://dx.doi. org/10.1590/1413-70542016406021616.

KRINSKI, D. and FOERSTER, L.A., 2017. Damage by Tibraca limbativentris Stål (Pentatomidae) to upland rice cultivated in Amazon rainforest region (Brazil) at different growth stages. Neotropical Entomology, vol. 46, no. 1, pp. 107-114. PMid:27558273.http:// dx.doi.org/10.1007/s13744-016-0435-5.

KRINSKI, D. and GODOY, A.F., 2015. First record of Helicoverpa armigera (Lepidoptera, Noctuidae) feeding on Plectranthus neochilus (Lamiaceae) in Brazil. The Florida Entomologist, vol. 98, no. 4, pp. 1238-1240. http://dx.doi.org/10.1653/024.098.0434.

KRINSKI, D. and PELISSARI, T.D., 2012. Occurrence of the stinkbug Edessa meditabunda F. (Pentatomidae) in differents cultivars of lettuce Lactuca sativa L. (Asteraceae). Bioscience Journal, vol. 28, no. 4, pp. 654-659.

KRINSKI, D., 2013a. Physalis angulata L. (Solanaceae): a potential host-plant of stink bugs Edessa meditabunda F. (Hemiptera, Pentatomidae). Biota Neotropica, vol. 13, no. 2, pp. 336-339. http://dx.doi.org/10.1590/S1676-06032013000200036.

KRINSKI, D., 2013b. First report of phytophagous stink bug in chicory crop. Ciência Rural, vol. 43, no. 1, pp. 42-44. http:// dx.doi.org/10.1590/S0103-84782012005000127.

KRINSKI, D., 2015. First report of Squash Vine Borer, Melittia cucurbitae (Harris, 1828) (Lepidoptera, Sessidae) in Brazil and South America: distribution extension and geographic distribution map. Check List, vol. 11, no. 3, pp. 1625, 1-3.

KRINSKI, D., FAVETTI, B.M. and BUTNARIU, A.R., 2012. First record of Edessa meditabunda (F.) on lettuce in Mato Grosso State, Brazil. Neotropical Entomology, vol. 41, no. 1, pp. 79-80. PMid:23950014.http://dx.doi.org/10.1007/s13744-011-0012-x. 
MARTINS, A.L. and KRINSKI, D., 2016. First record of the parasitoid Gonatopus flavipes Olmi, 1984 (Hymenoptera, Dryinidae) in Brazil's Amazon forest. Journal of Hymenoptera Research, vol. 50, pp. 191-196. http://dx.doi.org/10.3897/JHR.50.8897.

MARTINS, J.F.S., BARRIGOSSI, J.A.F., OLIVEIRA, J.V. and CUNHA, U.S., 2009. Situação do manejo integrado de insetos-praga na cultura do arroz no Brasil. Pelotas: EmbrapaClimaTemperado, 40 p. Documentos, no. 290.

NILAKHE, S.S., 1985. Ecological observations on spittlebugs with emphasis on their occurrence in rice. Pesquisa Agropecuária Brasileira, vol. 20, no. 4, pp. 407-414.

NILAKHE, S.S., MARTIN, P.B., VALÉRIO, J.R., KOLLER, W.W., SOUZA-FILHO, J.A.G. and SILVA, A.A., 1984. Sampling plans for spittlebug eggs in pastures of Brachiaria decumbens. Pesquisa Agropecuária Brasileira, vol. 19, no. 8, pp. 935-941.

NWILENE, F.E., TRAORE, A.K., ASIDI, A.N., SERE, Y., ONASANYA, A. and ABO, M.E., 2009. New records of insect vectors of rice yellow mottle virus (RYMV) in Côte d'Ivoire, West Africa. Journal of Entomology, vol. 6, no. 4, pp. 189-197. http://dx.doi.org/10.3923/je.2009.189.197.

ONASANYA, A., JOSEPH, A., OLUFOLAJI, D.B., EKPERIGIN, M.M., SERE, Y., NWILENE, F.E., KIEPE, P. and ONASANYA, R.O., 2012. RYMV serological detection in insect vector, distribution and transmission to rice cultivars. Trends in Applied Sciences Research, vol. 7, no. 1, pp. 46-56. http://dx.doi.org/10.3923/tasr.2012.46.56.

PALADINI, A. and CARVALHO, G.S., 2007. Description of three new species of Mahanarva (Hemiptera, Cercopidae, Ischnorhininae). Iheringia. Série Zoologia, vol. 97, no. 1, pp. 57-66. http://dx.doi.org/10.1590/S0073-47212007000100009.

PALADINI, A. and CARVALHO, G.S., 2013. Descriptions of two new species of Sphenorhina (Hemiptera, Cercopidae, Tomaspidinae) from the Neotropical region. Revista Brasileira de Entomologia, vol. 57, no. 2, pp. 165-168. http://dx.doi.org/10.1590/ S0085-56262013005000005.

PALADINI, A. and CAVICHIOLI, R.R., 2013. A new species of Aeneolamia (Hemiptera: Cercopidae: Tomaspidinae) from the Neotropical Region. Zoologia, vol. 30, no. 3, pp. 353-355. http:// dx.doi.org/10.1590/S1984-46702013000300016.

PALADINI, A. and CAVICHIOLI, R.R., 2014. Taxonomic notes on Mahanarva (Ipiranga) (Hemiptera, Cercopidae) with description of a new species. Zootaxa, vol. 3861, no. 5, pp. 479486. PMid:25283423.http://dx.doi.org/10.11646/zootaxa.3861.5.5.

PALADINI, A. and CAVICHIOLI, R.R., 2015. A new genus and new species of spittlebug (Hemiptera, Cercopidae, Ischnorhininae) from southern Brazil. Zoologia, vol. 32, no. 1, pp. 47-52. http:// dx.doi.org/10.1590/S1984-46702015000100007.

PALADINI, A. and CRYAN, J., 2012. Nine new species of Neotropical spittlebugs (Hemiptera: Cercopidae: Ischnorhininae). Zootaxa, no. 3519, pp. 53-68.
PALADINI, A., 2011. A new species of Ferorhinella with an unusual pattern of sexual size dimorphism (Hemiptera, Cercopidae, Tomaspidinae). Zootaxa, no. 2728, pp. 57-60.

PALADINI, A., TAKIYA, D.M., CAVICHIOLI, R.R. and CARVALHO, G.S., 2015. Phylogeny and biogeography of Neotropical spittlebugs (Hemiptera: Cercopidae: Ischnorhininae): revised tribal classification based on morphological data. Systematic Entomology, vol. 40, no. 1, pp. 82-108. http://dx.doi. org/10.1111/syen.12091

PECK, D., CASTRO, U., LÓPEZ, F., MORAleS, A., RODRÍGUEZ, J., LOPEZ, F. and RODRIGUEZ, J., 2001. First records of the sugar cane forage grass pest, Prosapia simulans (Homoptera: Cercopidae), from South America. The Florida Entomologist, vol. 84, no. 3, pp. 402-409. http://dx.doi. org/10.2307/3496499.

PECK, D.C., 2000. Reflex bleeding in froghoppers (Homoptera: Cercopidae): Variation in behavior and taxonomic distribution. Annals of the Entomological Society of America, vol. 93, no. 5, pp. 1186-1194. http://dx.doi.org/10.1603/0013-8746(2000)093[1186:RB IFHC]2.0.CO;2.

PUGLIESE, A. and TERRA, J.G., 1957. Uma nova praga na lavoura de arroz. Lavoura Arrozeira, vol. 11, pp. 1-9.

ROSSETTO, C.J., MARTINS, J.F.S., SCHMIDT, N.C. and AZZINI, L.E., 1978. Damage of grass spittlebugs Deois flavopicta and Deois schach to rice. Bragantia, vol. 37, no. 1, pp. 15-17.

ROSSETTO, C.J., SILVEIRA-NETO, S., LINK, D., VIEIRA, J.G., AMANTE, E., SOUZA, D.M., BANZATTO, N.V. and OLIVEIRA, A.M., 1972. Pragas do arroz no Brasil. In: Reunião do Comitê de Arroz para as Américas, 6-11 December 1971, Pelotas. Brasília: FAO, pp. 149-238. Contribuições técnicas da delegação brasileira.

SERE, Y., ONASANYA, A., NWILENE, F.E., ABO, M.E. and AKATOR, K., 2008. Potential of insect vector screening method for development of durable resistant cultivars to rice yellow mottle virus disease. International Journal of Virology, vol. 4, no. 2, pp. 41-47. http://dx.doi.org/10.3923/ijv.2008.41.47.

SOCIEDADE SUL-BRASILEIRA DE ARROZ IRRIGADO SOSBAI, 2005. Arroz irrigado: recomendações da pesquisa para o Sul do Brasil. Santa Maria: Sosbai, 159 p.

SOUZA, A.R.R. and NILAKHE, S.S., 1985. Avaliação de danos e controle químico das cigarrinhas-das-pastagens em culturas de arroz. Anais da Sociedade Entomológica do Brasil, vol. 14, no. 2, pp. $177-188$

THOMPSON, V., 1973. Spittlebug polymorphic for warning coloration. Nature, vol. 242, no. 5393, pp. 126-128. http://dx.doi. org/10.1038/242126a0.

WILSON, M.R. and CLARIDGE, M.F., 1991. Handbook for the identification of leafhoppers and planthoppers of rice. London: International Institute of Entomology, Wallingford, Oxon, $142 \mathrm{p}$. 